\title{
(10) Corneal Opacity: A Rare Manifestation of Cystic Fibrosis
}

\section{Kistik Fibrozisin Nadir Bir Komplikasyonu: Korneal Opasite}

Sevgi Pekcan, ${ }^{1}$ Deniz Doğru Ersöz, ${ }^{2}$ Mehmet Köse, ${ }^{3}$ Güzin Cinel, ${ }^{2}$ Murat İrkeç, Ebru Yalçın,

Uğur Özçelik, ${ }^{2}$ Nural Kiper, ${ }^{2}$

\section{Abstract}

Eye manifestations due to hypovitaminosis $A$ was observed in the follow-up of patients with cystic fibrosis. Herein, we describe an 11 -month-old infant with corneal opacity and growth retardation who was diagnosed as cystic fibrosis. To our knowledge, this is the first report in the literature of corneal opacity as a manifestation of cystic fibrosis. Furthermore, it is rare to encounter ophthalmic findings in cystic fibrosis at this age.

Key words: Cystic fibrosis, corneal opacity, hypovitaminosis $A$.

\section{Özet}

Kistik fibrozisli hastaların takibinde A vitamini eksikliğine bağlı göz bulguları görülebilmektedir. Korneal opasite ve gelişme geriliği ile başvurarak kistik fibrosis tanısı alan 11 aylık bir çocuğu sunuyoruz. Korneal opasite bulgusu ile tanı alan literatürde bildirilen ilk kistik fibrosis vakasıdır ve erken yaşta bu hastalarda göz bulguları nadirdir.

Anahtar Sözcükler: Kistik fibrozis, korneal opasite, vitamin A eksikliği.
Cystic fibrosis (CF) is the most prevalent inheritable chronic disease in Caucasian children, characterized chiefly by obstruction and infection of the airways and maldigestion (1). Ocular findings in CF mainly refer to the tear film and are related to tear hyposecretion and improper composition of tears, leading to dry-eye symptoms, considered by some authors as the primary CF eye manifestations (2-6). Herein, we describe an 11 -month-old boy diagnosed as CF with corneal opacity. To our knowledge, this is the first report in the literature of corneal opacity as an ocular manifestation of CF.

\footnotetext{
'Necmettin Erbakan University Meram Faculty of Medicine, Department of Pediatrics, Pediatric Pulmonology Unit, Konya ${ }^{2}$ Hacettepe University Faculty of Medicine, Pediatric Pulmonology Unit, Ankara,

${ }^{3}$ Erciyes University Faculty of Medicine, Pediatric Pulmonology Unit, Kayseri,

${ }^{4}$ Hacettepe University Faculty of Medicine, Department of Ophthalmology, Ankara, Turkey
}

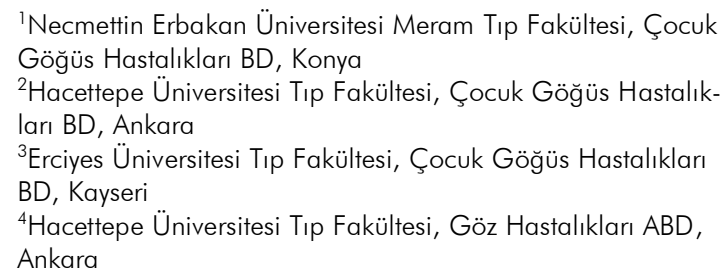
ları BD, Ankara

${ }^{3}$ Erciyes Üniversitesi Tıp Fakültesi, Çocuk Göğüs Hastalıkları BD, Kayseri

${ }^{4}$ Hacettepe Üniversitesi Tıp Fakültesi, Göz Hastalıkları ABD, Ankara

Submitted (Başvuru tarihi): 08.08.2012 Accepted (Kabul tarihi): 05.09.2012

Correspondence (IIletişim): Sevgi Pekcan, Necmettin Erbakan University Meram Faculty of Medicine, Department of Pediatrics,

Pediatric Pulmonology Unit, Konya

e-mail: sevgipekcan@yahoo.com 


\section{CASE}

An 11-month-old male child was referred to Hacettepe University Children's Hospital with diarrhea, cough and growth retardation. He was born at full term following an uncomplicated pregnancy. From birth, he had 6-8 large, unformed, greenish stools per day. Upon physical examination, his weight and height were $3,500 \mathrm{~g}(<3 \mathrm{p})$ and $57 \mathrm{~cm}(<3 p)$, respectively. Marked wasting of muscle mass was noted. Subcutaneous lipoid tissue was decreased and his skin was pale. His scalp hair was diffusely sparse, light brown, and thin. Ocular examination demonstrated that visual acuity for each eye was limited to hand motion. Marked conjunctival hyperemia with dry and keratinized epithelium was present bilaterally. Bilateral corneal opacity was demonstrated (Figure 1).

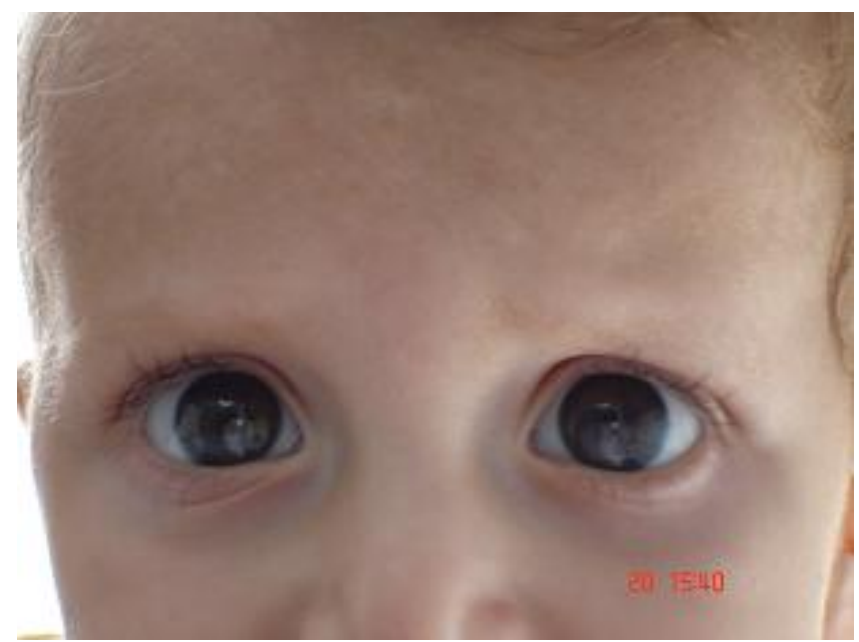

Figure 1: Cystic fibrosis case with corneal opacity.

Laboratory test results were as follows: white blood cell count: $25,000 / \mathrm{mm}^{3}$; hemoglobin: $6.6 \mathrm{~g} / \mathrm{dl}$; and platelets: $174,000 / \mathrm{mm}^{3}$. Electrolytes and renal and liver functions were normal. Chest roentgenogram was normal. The patient's serum zinc level was $92 \mu \mathrm{g} / \mathrm{dl}$ (63-110), serum vitamin A level was $20.2 \mathrm{mg} / \mathrm{dl}$ (normal range: 30-60 $\mathrm{mg} / \mathrm{dl}$ ), and serum vitamin $\mathrm{E}$ level was $0.49 \mathrm{mg} / \mathrm{dl}$ (normal range: $0.8-1.5 \mathrm{mg} / \mathrm{dl}$ ). A nasopharyngeal aspirate culture yielded pseudomonas aeruginosa, and antipseudomonal antibiotics were initiated. Stool steatocrit was positive. Sweat chloride was elevated at $72 \mathrm{mEq} / \mathrm{L}$. CF was suspected and he was commenced on pancreatic enzyme replacement. Because of hypovitaminosis $A$ and $\mathrm{E}$, the patient was supplemented with multivitamins. Corneal opacity resolved (Figure 2) within three months of commencing pancreatic enzyme and multivitamin supplementation. At 18 months of age, he achieved the 25th50th percentile for both weight and height. Molecular genetic studies revealed a homozygous $\Delta F 508$ genotype, confirming CF.

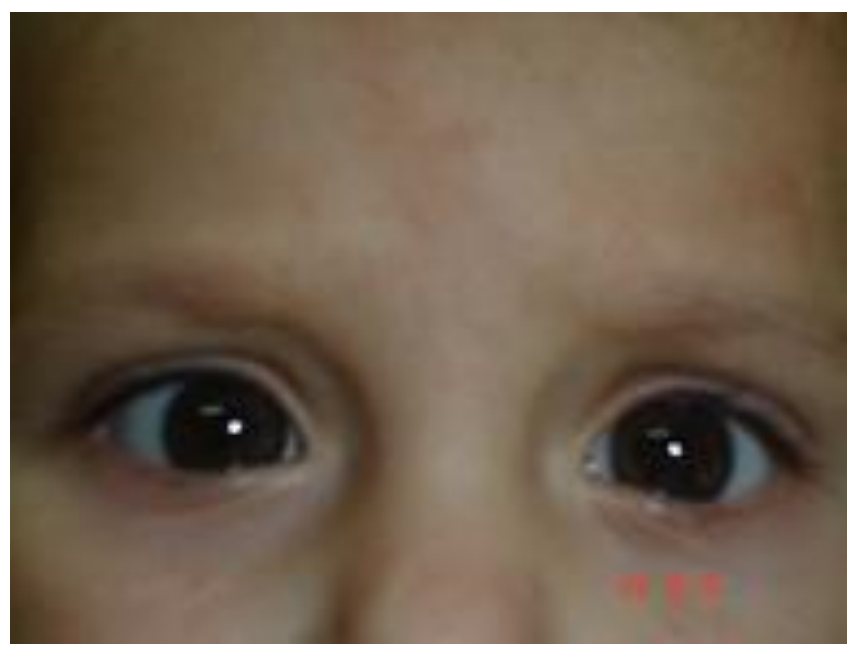

Figure 2: Resolution of corneal opacity on follow-up 3 months after admission.

\section{DISCUSSION}

Cystic fibrosis patients frequently present complex nutritional problems caused by the association of the underlying disease process and the effects of pancreatic exocrine insufficiency, which occurs in approximately $90 \%$ of CF patients (1). Steatorrhea, a consequence of decreased fat digestion and absorption, may be associated with vitamin deficiencies, including vitamin $A$ (7).

In children, manifestations of vitamin A deficiency include poor skeletal growth, hepatomegaly, increased intracranial pressure, and ocular changes (7). The ocular manifestations of hypovitaminosis $A$ are conjunctival, and corneal xerosis, keratomalacia including ulceration, night-blindness, severe loss of visual acuity, flecked retina, and pseudotumor cerebri (2-8). Ocular changes in the published literature occur in the adolescent and early adult periods. In our patient, the ocular examination revealed corneal opacity behind the conjunctival hyperemia with dry and keratinized epithelium. Corneal opacity as an ocular manifestation of CF has not been published previously. The patient was just 11 months old, and thus to our knowledge is the youngest CF patient with ocular manifestations.

Vitamin A deficiency causes a loss of goblet cells in the conjunctiva and a prominent decrease in microvilli and microplicae of the conjunctiva and cornea. In addition, epithelial cells showed poor fibrous development and abnormal distribution of chromatin in the nucleus. Vitamin A deficiency induces degeneration and disappearance of photoreceptor cells of the retina and myelin lamellae in myelinated optic nerve fibers (9). Not only vitamin 
A, but also some trace elements such as zinc, copper, selenium, manganese, and vitamins $\mathrm{C}, \mathrm{B} 12$ and $\mathrm{E}$ are necessary for the maintenance of cellular structure and metabolism (9). Therefore, in some studies, not only vitamin $A$ but also zinc and vitamin $E$ treatment help to resolve the ocular manifestations of CF patients $(9,10)$. Our patient had low vitamin $\mathrm{A}$ and $\mathrm{E}$ levels and a normal zinc level. Unfortunately, we could not examine the trace elements in our center. He was treated with pancreatic enzyme replacement and multivitamins, and the corneal opacity was resolved within three months. Presentation in early infancy and resolution of the corneal opacity with pancreatic enzyme and multivitamin supplementation suggest that not only hypovitaminosis $A$, but also deficiency of several micronutrients due to the pancreatic insufficiency, could be responsible for the ocular changes in CF patients.

In conclusion, ocular changes can be seen in CF patients as early as infancy. Corneal opacity is one of the ocular manifestations in CF patients. Efficient pancreatic enzyme and multivitamin supplementation should resolve the problem.

\section{CONFLICTS OF INTEREST}

None declared.

\section{REFERENCES}

1. Proesmans M, Vermeulen F, De Boeck K. What's new in cystic fibrosis? From treating symptoms to correction of the basic defect. Eur J Pediatr. 2008; 167: 839-49. [CrossRef]

2. Ansari EA, Sahni K, Etherington $\mathrm{CH}$, Morton A, Conway $S P$, Moya $E$, et al. Ocular signs and vitamin A status in pa- tients with cystic fibrosis treated with daily vitamin A supplements. Br J Ophthalmol 1999; 83: 688-91. [CrossRef]

3. Huet F, Semama D, Mainqueneau C, Charavel A, Nivelon $\mathrm{JL}$. Vitamin A deficiency and nocturnal vision in teenagers with cystic fibrosis. Eur J Pediatr 1997; 156: 949-51. [CrossRef]

4. Morkeberg JC, Edmund C, Prause JU, Lanng S, Koch C, Michaelsen KF. Ocular findings in cystic fibrosis patients receiving vitamin A supplementation. Graefes Arch Clin Exp Ophthalmol 1995; 233: 709-13. [CrossRef]

5. Rayner RJ, Tyrrell JC, Hiller EJ, Marenah C, Neugebauer MA, Vernon SA, et al. Night blindness and conjunctival xerosis caused by vitamin A deficiency in patients with cystic fibrosis. Arch Dis Child 1989; 64: 1151-6. [CrossRef]

6. Kalayci D, Kiper N, Ozcelik U, Gocmen A, Hasiripi H. Clinical status, ocular surface changes and tear ferning in patients with cystic fibrosis. Acta Ophthalmol Scand 1996; 74: 563-5. [CrossRef]

7. Eid NS, Shoemaker LR, Samiec TD. Vitamin A in cystic fibrosis: case report and review of the literature. J Pediatr Gastroenterol Nutr 1990; 10: 265-9. [CrossRef]

8. Fujikawa A, Gong H, Amemiya T. Vitamin E prevents changes in the cornea and conjunctiva due to vitamin $A$ deficiency. Graefes Arch Clin Exp Ophthalmol 2003; 241: 287-97. [CrossRef]

9. Amemiya T. The eye and nutrition. Jpn J Ophthalmol 2000; 44: 320. [CrossRef]

10. Tinley CG, Withers NJ, Sheldon CD, Quinn AG, Jackson AA. Zinc therapy for night blindness in cystic fibrosis. J Cyst Fibros 2008; 7: 333-5. [CrossRef] 